УДК 7.03;7:001.12

\title{
ТВОРЧЕСТВО Н.Н. САПУНОВА
}

\section{Филиппова Ольга Николаевна \\ руководитель архива Политехнический музей, г. Москва}

\begin{abstract}
Аннотация: Данная публикация посвящена творчеству замечательного русского художника Николая Николаевича Сапунова (1880-1912). Ученик И.И. Левитана, В.А. Серова и К.А. Коровина, он был тесно связан с реалистической традицией, но принадлежал уже к поколению новаторов начала XX столетия - к «Голубой Розе» - и может рассматриваться, как одна из крупнейших фигур русского предавангарда [3, с. 10]. Живописец по призванию, он работал в традиционных жанрах пейзажа, портрета, натюрморта, явился создателем нового жанра - театрализованной бытовой картины - и был одним из самых ярких и выдающихся мастеров театральнодекорационного искусства своего времени.

Ключевые слова: Творчество Н.Н. Сапунова, дарование, профессиональный художник, педагоги, мастера «Голубой розы», пейзажи, натюрморты, театр, постановки, выставки.
\end{abstract}

\section{THE CREATIVE WORK OF N.N. SAPUNOV}

Filippova Olga Nikolaevna

\begin{abstract}
This publication is dedicated to the work of the remarkable Russian artist Nikolai Nikolaevich Sapunov (1880-1912). A student of I.I. Levitan, V.A. Serov and K.A. Korovin, he was closely associated with the realistic tradition, but he belonged to the generation of innovators of the early XX century - the "Blue Rose" - and can be considered as one of the largest figures of the Russian preavant-garde [3, p. 10]. A painter by vocation, he worked in the traditional genres of landscape, portrait, and still life, was the creator of a new genre-theatrical household paintings-and was one of the brightest and most outstanding masters of theatrical and decorative art of his time.
\end{abstract}


Key words: The creative work of N.N. Sapunov, talent, professional artist, teachers, masters of the "Blue rose", landscapes, still-lifes, theater, productions, exhibitions.

Николай Николаевич Сапунов родился 17 (29) декабря 1880 года в Замоскворечье в небогатой купеческой семье. Дарование его, как художника, проявилось рано. В тринадцатилетнем возрасте он поступил в Московское училище живописи, ваяния и зодчества, где обучался в течение десяти лет. Здесь он рос, зрел, как профессиональный художник и формировался, как личность. Судьба была необычайно благосклонна к Н.Н. Сапунову. Она свела его с крупнейшими деятелями русской культуры рубежа XIX-XX веков. Среди его педагогов были И.И. Левитан, В.А. Серов и К.А. Коровин. Контакты Н.Н. Сапунова с К.А. Коровиным оказались значительно более длительными и продолжались после завершения учебы в Московском училище. Увлечение К.А. Коровиным передовой училищной молодежью было тогда всеобщим. В 1901 году К.А. Коровин был приглашен В.А. Серовым преподавать и возглавил вместе с ним высшую художественную мастерскую портрета и жанра. Через эту мастерскую прошли все мастера «Голубой розы» (на примере П.В. Кузнецова, Н.П. Крымова, С.Ю. Судейкина, Н.Д. Милиоти и др.) [8, с. 8]. Красивый, обаятельный, К.А. Коровин казался баловнем судьбы. Его темпераментная широкая живопись была пронизана оптимизмом, влюбленностью в солнце, воспринималась, как смелое новаторство, противопоставленное серости и прозаизму позднего передвижничества, и казалось воплощением творческой свободы. Влияние К.А. Коровина на Сапунова было более непосредственным и сразу же проявилось в творчестве молодого художника. Так, в отличие от «левитановской» по настроению грустной, серой «Зимы» (1900), пейзаж «Цветушие яблони» (1902) был пропитан оптимизмом К.А. Коровина [8, с. 8]. Задачей Н.Н. Сапунова в этой работе была передача солнечного света, ощущения весны, как радостного возрождения жизни, поры цветения.

Молодой художник со всей откровенностью стремился овладеть его манерой письма. Интерес к жанру натюрморта возник у Н.Н. Сапунова также под влиянием К.А. Коровина, который в 1900-е годы как раз много работал в этом жанре, любил изображать цветы, особенно розы. И Н.Н. Сапунов пишет в те же годы множество натюрмортов из роз. Подчас их можно спутать с 
коровинскими. Однако по существу своему мировидение молодого художника было иным. Оно очень рано начало формироваться, как символистское и достаточно скоро проявилось во всей своей силе. Не случайно, что именно Н.Н. Сапунов был создателем образа голубой розы, той самой, что стала символом одноименной выставки 1907 года, украсила ее каталог и явилась знаком символистского движения в русском искусстве. Он был одним из самых активных деятелей голуборозовского содружества. Но при всем том влияние К.А. Коровина всегда оставалось в нем сильным и давало о себе знать в отдельных его работах до конца жизни. Если ранние живописные работы мастера говорят о его стремлении соединить вместе впечатления от музыки и изобразительного искусства («Ночной ландшафт», «Ноктюрны», «Пастораль», «Пиковая дама», все - 1903-1904 гг.), то в более поздних его картинах, показывающих народные гулянья и маскарады, отразился интерес художника к яркой, праздничной стороне жизни («Карусель», 1908; «Ночной праздник», не позднее 1909; «Ночь», 1900-е гг.; «Весна. Маскарад», 1912) [6, с. 191]. На новом этапе главной темой творчества Н.Н. Сапунова становится его картина: «Карусель» [8, с. 16]. На первых порах образ этот заинтересовал художника своей декоративностью и как выражение национального духа, образец бытовой русской архитектуры, в которой были отражены народные вкусы, представления о красоте (варианты работ хранятся в ГТГ и в ГМИИ Республики Татарстан). Вообще же масленичные гулянья, ярмарки с их балаганами и каруселями, как известно, привлекали многих мастеров начала XX столетия. Но Н.Н. Сапунов не ограничился таким подходом к данном теме. Она становится руководящим началом всего его творчества.

В окончательном варианте - картине «Карусель» (1908) из собрания Государственного Русского музея в Петербурге, ставшей главным созданием Н.Н. Сапунова, - этот мотив вырастает в образ большой обобщающей силы, в символ вечного кружения жизни - шумной, красивой, казалось бы, веселой, но по сути, таящей в себе чувство трагической предопределенности Судьбы [8, с. 16]. «Карусель» принадлежит к числу эпохальных явлений русской живописи эпохи символизма и предавангарда [8, с. 16]. Она декоративна и похожа на сияющий всеми красками ковер. Но при этом цвет здесь исполнен такой силы эмоции, что кажется, будто бы краски звучат. Живопись здесь подобна экспрессивной музыке, поражающей глубиной и силой драматизма. Здесь со всей откровенностью заявлены новые принципы художественного 
мышления. Картина является не просто изображением сцены народного гулянья, а живописным воплощением символистского восприятия бытия. Н.Н. Сапунов здесь показывает смелость подхода к передаче реальности, используя несколько точек зрения; применяет прием примитивизации, обращаясь к народной деревянной игрушке, к принципам балаганного искусства с присущими ему «разухабистостью» и откровенным огрублением форм и цвета [8, с. 16]. Обыденное занятие, такое, как чаепитие, часто превращается на холсте Н.Н. Сапунова в необычайное красочное действо, как мы видим в его картине: «Чаепитие» (1912) [6, с. 192]. «Здесь тот же балаганчик жизни, что и в картине на сюжет феерии А. Блока, но без театральной романтики, без стремления к каким-либо - пусть призрачным - идеалам» $[5$, с. 3]. В вышеперечисленных композициях, равно, как и в натюрмортах, Н.Н. Сапунов сближается с представителями художественного объединения: «Мир искусства» [6, с. 192]. Мирискусникам было важно показать предметы, красивые вещи сами по себе, а не, как таинственные оболочки неведомых сущностей, что было характерно для живописи символистов. Нарядные позолоченные вазы с изящными рисунками, пышные цветочные букеты, гроздья винограда, яблоки, груши, абрикосы - все это просто чудесные вещи, поражающие зрителя своим великолепием, в них нет никакого дополнительного тайного смысла.

Любимые мотивы натюрмортов Н.Н. Сапунова - это цветы в вазах из фарфора или цветного стекла, изображенные на мерцающем фоне шелковых драпировок и занавесей. В этих композициях преобладают разнообразные оттенки голубого, золотистого, розового, синего и сиреневого («Пионы», 1908; «Натюрморт с вазой и цветами», 1910; «Голубые гортензии», 1910; «Натюрморт с автопортретом», 1910-1911; «Цветы и фарфор», 1912; «Вазы, цветы и фрукты», 1912) [6, с. 193]. «Колористическое мастерство Н.Н. Сапунова особенно ярко сказалось в его «Натюрморте с автопортретом» (1910-1912). В самом углу, справа, художник представил свое изображение. Это единственный известный его автопортрет, и поместил он его здесь, вероятно, шутки ради: Н.Н. Сапунов в жизни любил напускать на себя чудаковатость, таинственность и эксцентричность» [5, с. 3]. Это как бы был своеобразный живописный реквием самому себе. Элемент трагического с особой силой проявлялся в искусстве Н.Н. Сапунова последних двух лет, как в станковых работах, так и в театральных спектаклях. При этом гротеск 
обретает все более острые формы. «Для Дома интермедий, основанного в 1910 году в Петербурге по инициативе В.Э. Мейерхольда, Н.Н. Сапунов создал несколько декораций, в частности для двухактной пантомимы по А. Шницлеру: «Шарф Коломбины» и для пасторали М.А. Кузмина: «Голландка Лиза» (к «Голландке Лизе» - в соавторстве с А.А. Араповым)» [5, с. 2]. «Вскоре обе пьесы на основе трагического гротеска были запечатлены Н.Н. Сапуновым в станковых картинах, одна из которых - это «Шарф Коломбины. Сцена свадьбы Арлекина и Коломбины» (1910) - сейчас хранится в Государственном центральном театральном музее имени А.А. Бахрушина, а другая - «Голландка Лиза» (1910) - в Государственной Третьяковской галерее» [5, с. 2]. Важно отметить, что еще в ранние годы, когда Н.Н. Сапунов был учеником Московского училища, то он приобщился к театру. Он участвовал в оформлении всех училищных спектаклей, работал подмастерьем у художника МХT, Заслуженного деятеля искусств РСФСР Виктора Андреевича Симова.

В начале 1900-х годов через К.А. Коровина Н.Н. Сапунов и его друзья познакомились и сблизились с С.И. Мамонтовым, который в ту пору вновь набирал силы после перенесенной жизненной трагедии. Молодые художники «новой волны» стали ему в этом опорой [8, с. 11]. Именно они работали в новой оперной антрепризе С.И. Мамонтова в московском театре Эрмитаж, где в сезоне 1902 / 1903 в их оформлении были поставлены оперы К.В. Глюка «Орфей», Э. Гумпердинка: «Гензель и Гретель», М. Эспозито: «Каморра» и другие [8, с. 11]. В 1902 году К.А. Коровин доверил своим ученикам Н.Н. Сапунову и П.В. Кузнецову оформление «Валькирии» Р. Вагнера в Большом театре в Москве [8, с. 11]. Также очень важной оказалась встреча Н.Н. Сапунова с В.Э. Мейерхольдом в 1905 году в только, что возникшей при МХТ экспериментальной Студии на Поварской. Молодые художники были полны желания воплотить здесь мечту о создании символистского театра нового типа. Для первой постановки была избрана драма Мориса Метерлинка: «Смерть Тентажиля», написанная в 1894 году [8, с. 11]. Живописная пластика обретала на сцене такого театра глубокую эмоциональность. Рождающиеся в подсознании смутные интуитивные ощущения определяли стилистические особенности живописного решения, характер колористической гаммы той, или иной сцены. Работа с В.Э. Мейерхольдом оставила большой след в творчестве художника. Присущие его дарованию эмоциональность и 
музыкальность мироощущения обрели качества стабильности, наполнились внутренним смыслом, стали органичной формой выражения в живописи символистской идеи. Театр был в ту пору для Н.Н. Сапунова страной Чудес, миром волшебства и красоты. Прием театрализации в станковой живописи на раннем этапе творчества явился средством возвышения, поэтизации жизни. Многие станковые произведения Н.Н. Сапунова середины 1900-х годов «Балет», «Маскарад», «Менуэт» и другие - представляют собой по существу сценические композиции и мало чем отличаются от ранних театральных эскизов [8, с. 12].

Его ранний: «Балет» (1903-1904) появился тогда, когда само сценическое действие становится сюжетом картин Н.Н. Сапунова [8, с. 12]. А, в прозрачном, серебристом, словно, созданном из паутины и газа, кажущимся, ускользающим видением: «Балете» 1905 года задача изображения театра сменилась у художника задачей живописно-пластического выражения чудесной способности театра преображать реальность в волшебство, в сказку, в мечту [8, с. 12]. Вот тогда-то и пришла настоящая удача к художнику. Вообще, в этот период творчество Н.Н. Сапунова было очень близко эстетическим принципам: «Мира искусства» [8, с. 12]. Многие сапуновские произведения первой половины 1900-х годов были созданы на основе именно этих принципов. Среди работ такого рода можно назвать стилизованный под XVIII век: «Портрет артистки Андреевой» (1905), вполне «сомовские» по мотиву и характеру исполнения это: «В парке. Влюбленные» (1904), «Арлекин и дама. На маскараде» (1903-1904) и ряд других [8, с. 12]. Н.Н. Сапунов в 1904 году вместе с группой художников «кузнецовского кружка» выступил на выставке: «Алая Роза» в Саратове. Он представил восемь произведений, пять из них были на музыкальную тему - это «Ноктюрн», «Пастораль», «Пиковая дама» (музыка П.И. Чайковского) и др. Год спустя на выставке Московского товарищества художников Н.Н. Сапунов выставил еще одно живописное воплощение музыки П.И. Чайковского - «Ромео и Джульетту», поразившее современников своей эмоциональной выразительностью [8, с. 12]. В 1907 году на сенсационной в художественной жизни России выставке: «Голубая роза» в Москве Н.Н. Сапунов был представлен семью работами (среди них были его известные: «Маскарад» 1907 года и «Балет» 1905 года). Выставка «Голубая роза» явилась вершиной русского символизма 1900-х годов и одновременно вызвала разноречивые отклики [8, с. 15]. Дальше в этом направлении 200 
двигаться было некуда. Молодые художники оказались перед выбором - идти вслед за авангардом или искать свой особый путь возрождения живописной пластики. И они избрали второе. 1907 год стал переломным в истории русского символизма в целом и для каждого из художников в отдельности, в т.ч. и для Н.Н. Сапунова.

Вскоре после выставки: «Голубая роза» в том же году на Пятой выставке Союза русских художников наряду с нежными: «Голубыми гортензиями» (1907), являющимися еще истинным выражением самого духа голуборозовской живописи, Н.Н. Сапунов выставил картину: «Пляска смерти» (1907), поразившую непривычной для голуборозовцев сочностью цвета и экспрессивностью выражения чувств [8, с. 15]. В отличие от многих его коллег по группе: «Голубая роза» художник не испытал горечи сомнений. Все события в его жизни происходили стремительно и очень быстро [8, с. 15]. Ему оставалось не так долго жить до трагической гибели. Жизнь талантливого художника оборвалась в 1912 году, когда он, катаясь на лодке, утонул. Место его гибели было - Териоки под Санкт-Петербургом. А саму его гибель предсказала ему гадалка еще в 1902 году, когда он с друзьями по училищу путешествовал по Италии. И быть может, предчувствие скорого конца породило ту необычайную стремительность, с которой теперь творил Н.Н. Сапунов, словно, торопясь, успеть высказаться, и ту трагичность мироощущения, что пронизывает все творчество художника последнего пятилетия. Тема Смерти, неотвратимого Рока, неумолимой Судьбы стала основной мыслью его искусства этого времени.

Таким образом, Н.Н. Сапунов прожил очень короткую жизнь, но эта короткая жизнь была до предела сконцентрирована, напряжена, была очень активна. Художник формировался в некоем вихревом потоке новаторства, возникшем тогда в русской культурной жизни. Но это было время бурного натиска символизма в литературе, театре, живописи, время, когда менялось все и вся, складывались новые эстетические принципы, искусство начинало осознавать себя главной движущей силой общества. Художник оказался в самом центре всех этих перемен и сам был их участником. 


\section{Список литературы}

1. Алпатов М.В. Николай Николаевич Сапунов. [1880-1912] / М.В. Алпатов, Е.А. Гунст. - М.: Искусство, 1965. 48 с.: ил.

2. Волошин М.А. Памяти Н.Н. Сапунова // Аполлон. - 1914. №4. С. 5-7.

3. Гофман И.М. Николай Сапунов = Nikolai Sapunov. - М.: Типография новости, 2003. 481 с.: ил.

4. Гофман И.М. Стихии Николая Сапунова // Наше наследие. - 2004. №71. - С. 40-53.

5. Сапунов Николай Николаевич: альбом репродукций / Вступ. статья Евг. Гунст. - М.: Изобразительное искусство, 1974. 4 с.: ил.

6. Николай Николаевич Сапунов (1880-1912) // Мастера натюрморта / автор-составитель Г.В. Дятлева. - М.: Вече, 2002. - С. 191-193.

7. Николай Сапунов: альбом / Михаил Киселев. - Москва: Белый город, 2002. 47 с. - (Мастера живописи).

8. Николай Сапунов. 1880-1912. Выставка произведений: каталог. Москва, 2003. 69 с.

9. Филиппова О.Н. Натюрморт в творчестве Николая Сапунова // Искусство Евразии. - 2019. - №1(12). - C. 26-39. DOI: 10.25712/ASTU.25187767.2019.01.002. [Электронный pecypc] URL: https: // readymag.com / u50070366/1329235/8/.

10. Эфрос А.М. Мастера разных эпох: [сборник статей] / А.М. Эфрос; [сост. М.В. Толмачев]. - М.: Советский художник, 1979. 336 с.: ил. (Библиотека искусствознания). 